\title{
The Effect of Time on Apoptosis Changes Following Ischemia-Reperfusion in Isolated Heart of Rats
}

\author{
Yusef Dostar ${ }^{1}$, Alireza Gorjani², Mehrdad Hashemi ${ }^{3}$, Rambod Rezapour Shahir $^{4}$
}

${ }^{1}$ Pathology ward of the Faculty of Veterinary, Islamic Azad University, Tabriz Unit, Tabriz, Iran. ${ }^{2}$ Pharmacology ward of the Faculty of Pharmacology, Tabriz University of Medical Sciences, Tabriz, Iran. ${ }^{3}$ Faculty of Medicine, Tehran Medical Ward- Molecular Genetic department, Research and Science Unit, The Islamic Azad University, Tehran, Iran. ${ }^{4}$ Graduate of Veterinary, The Islamic Azad University-Tabriz, Tabriz, Iran.

\begin{abstract}
Background and objective: To study the time-dependent effects of ischemia - reperfusion on myocardium cells. Methodology: Male SD rats (270-330gr) were randomly grouped in four groups of 10 in an experimental study. After anesthesia using pentobarbital sodium (50-60 IP- $\mathrm{kg} / \mathrm{mg}$ ) the rats' hearts in the treatment groups were isolated immediately and connected to langendorff apparatus with krebs solution at $37^{\circ} \mathrm{C}$ and a fixed pressure. During stabilization, $30 \mathrm{~m}$ ischemia and 60,90 , and $120 \mathrm{~min}$ reperfusion was carried out on the hearts. Hearts of the control group remained intact. Immunhistochemistry of apoptotic cells was performed using TUNEL POD Kit and positive TUNEL myocardium cells of each group, in five microscopic view fields, was counted. The results were represented as mean \pm SD. Findings: Apoptotic cell counts in control group was $1 \pm 0.4$, and this figure in the treatment groups $\mathrm{T} / 60 \mathrm{~min}, \mathrm{~T} / 90 \mathrm{~min}$, and $\mathrm{T} / 120 \mathrm{~min}$ was $2.0 \pm 0.5,3.0 \pm 0.3$, and $6.0 \pm 0.3$ respectively. Comparison between the treatment groups and control group was carried out using one-way ANOVA and the results showed no significant difference between the groups $\mathrm{T} / 90 \mathrm{~min}$ and $\mathrm{T} / 120 \mathrm{~min}$ and the groups $\mathrm{T} / 60$ and control ( $p>0.05)$. However, the differences between the groups $\mathrm{T} / 120 \mathrm{~min}$ and $\mathrm{T} / 60 \mathrm{~min}(\mathrm{p}<0.001)$ and groups $\mathrm{T} / 120 \mathrm{~min}$ and $\mathrm{T} / 90 \mathrm{~min}(\mathrm{p}<0.01)$ was significant. Conclusion: The study showed that ischemia-reperfusion time can be effective on apoptotic changes of myocardium cells of heart.
\end{abstract}

Keywords: Ischemia -reperfusion- apoptosis- infraction

Asian Pac J Cancer Biol, 2 (4), 77-80

\section{Introduction}

Necrosis and apoptosis are two separate pathways of cell death in myocardium cells. In fact, there is a correlation between ischemia (I) and reperfusion (R) and biological and morphological specifications of cardiocytes under necrosis and apoptosis are very similar. Necrosis is usually referred to as random or pathologic cell death that is coincident with severe cell inflammation and split, cytoplasm protein coagulation and denaturation, breakdown and destruction of cell internal organelles and severe inflammatory response. On the contrary, apoptosis is a programmed and genetically controlled cell death. The main morphological features of apoptosis are cellular leakage, chromatin condensation, formation of cytoplasm blebbing and apoptotic objects that happen without
Submission Date: 09/15/2017Ａcceptance Date: 11/25/2017

losing integrity of cell membrane and inflammatory response. Although necrosis and apoptosis mechanisms are different, there are common features between them in pathological conditions [1-4]. Several studies have shown that ischemia-reperfusion induces apoptosis of myocardia cells in vivo; still, there is an ongoing debate if apoptosis starts with I or R. Gutlib et al. found that the traces of touchstone of apoptosis - i.e. nucleosome fragments of DNA- were found in rabbits' ischemic myocardium $30 \mathrm{~min}$ after infraction and $4 \mathrm{hrs}$ after reperfusion; however, this was not found in ischemic myocardium. Based on their surveys, the authors proposed that apoptosis only happens with reperfusion [5].

A brief review of the pathology literature indicated that abnormal apoptosis appears in many disorders and diseases. There are a few diseases known in which apoptosis plays

Corresponding Author:

Dr. Mehrdad Hashemi

Faculty of Medicine, Tehran Medical Ward- Molecular Genetic department, Research and Science Unit, Islamic Azad University, Tehran, Iran. Email: hashemi_mehrdad@yahoo.com 
no role and a major part of pathogens of diseases can be explained by taking into account the role of apoptosis. Studies have shown that short and limited periods of in vitro ischemia-reperfusion in the right kidney induced apoptosis, while prolonged ischemia induced necrosis. Gutlib et al. demonstrated that ischemia-reperfusion induced apoptosis in myocytes of the rat and elaborated on the role of $\mathrm{pH}$ and ATPase in apoptosis following reperfusion. Piot et al. showed that ischemia-reperfusion in the rat's heart could be a sign of apoptosis and then they found the evidences after a long reperfusion of coronary blood flow. Although, they managed to explain apoptosis changes following ischemia-reperfusion, they failed to determine how much apoptosis was induced after each period of trivial preconditioned ischemia $[5,6]$. Leski studied the probable effects of ischemia-reperfusion in the case of coronary veins angioplasty and reported that increase of reperfusion time was effective on the post-surgery side-effects $[5,7]$. Heart infraction pathology is featured with several factors and conditions, and gradual loss of myocardium is one of the top pathologic issues. Over the years, we have been provided with a great deal of information about the role of post-infraction and ischemia-reperfusion apoptosis and that the both phenomena highlight importance of apoptosis. In light of this, the possibility to limit myocardium cell death through preventing apoptosis is potentially important in treating heart infraction and adopting an optimum length of time of ischemia-reperfusion $[6,8]$. Based on the findings of previous studies, the present one is an attempt to survey the role of time in ischemia-reperfusion of myocardium tissues of rats' heart.

\section{Materials and Methods}

Through an experimental study, male rats (SD; 250-300 gr) were randomly categorized in four groups of ten (one control and three treatment groups). The subjects were anesthetized using pentobarbital sodium (50-60 $\mathrm{IP}-\mathrm{kg} / \mathrm{mg}$ ) and immediately the hearts were isolated and connected to langendorff apparatus with krebs solution containing carbogen gas at $37^{\circ} \mathrm{C}$ and fixed pressure. The subjects in the treatment groups received standard krebs solution during stabilization, 30mins limited ischemia,

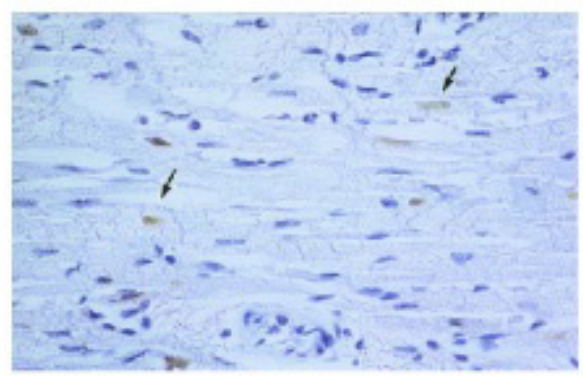

Figure 1. Sectional Photomicrograph of Myocardium Tissue of The Rats in the Treatment Group After 120min Reperfusion. Positive TUNEL cells are spotted by arrows (TUNEL staining, magnification:100X) and 60,90 , and $120 \mathrm{~min}$ reperfusion. The groups were labeled as $\mathrm{T} / 60 \mathrm{~min}, \mathrm{~T} / 90 \mathrm{~min}$, and $\mathrm{T} / 120 \mathrm{~min}$ based on ischemia-reperfusion time. The subjects in the control groups did not have ischemia-reperfusion. The hearts of the treatment group, after the reperfusion, were covered by fixative and kept in autotechnicon filled with formalin, ethanol, xylenol, and paraffin. Afterward, apoptosis detecting method (TUNEL assay) was implemented by sectioning the specimens. Apoptotic cells number in five random views of each specimen was counted under optical microscope. Data analyses were carried out using One-way ANOVA and Bartlett's test and the results were reported as mean score \pm standard deviation.

\section{Implementation of TUNEL assay}

1. After removing paraffin and hydrating, the prepared sections were exposed to proteinase $\mathrm{K}$ enzyme and rinsed by PBS solution after incubation $\left(30 \mathrm{~min}, 37^{\circ} \mathrm{C}\right)$.

2. Tissue sections were exposed to TUNEL reaction mixture $\left(50 \mu 1,60 \mathrm{~min}, 37^{\circ} \mathrm{C}\right)$ and then rinsed by PBS solution.

3. After incubation with Converter-POD $(50 \mu 1,30 \mathrm{~min}$, $37^{\circ} \mathrm{C}$ ) the sections were rinsed by PBS and exposed to $\mathrm{DAB}$ for $20 \mathrm{~min}$ at $25^{\circ} \mathrm{C}$.

4. The sections were rinsing by PBS solution and stained by blue toluidine $[1,9]$.

\section{Results}

Microscopic examinations showed an increase in condensation of chromatin and fragmentation of cell nucleuses and development of chromatin crescent in some samples. Due to cell DNA fragmentation that was mostly a factor of 180-200 base pairs, TUNEL staining appeared as light and dark brown in the myocardium

Table 1. Mean Score, SD, and SE of Number of Apoptotic Cells in Treatment and Control Groups

\begin{tabular}{lccc}
\hline Groups & mean score & Mean $\pm \mathrm{SD}$ & Mean $\pm \mathrm{SE}$ \\
\hline $\mathrm{T} / 60 \mathrm{~min}$ & 2.4 & $2.4 \pm 1.1$ & $2.4 \pm 0.5$ \\
$\mathrm{~T} / 90 \mathrm{~min}$ & 3.8 & $3.8 \pm 0.8$ & $3.8 \pm 0.3$ \\
$\mathrm{~T} / 120 \mathrm{~min}$ & 6.0 & $6 \pm 0.707$ & $6 \pm 0.316$ \\
Control & 1.6 & $1.6 \pm 80$ & $1.6 \pm 0.4$ \\
\hline
\end{tabular}

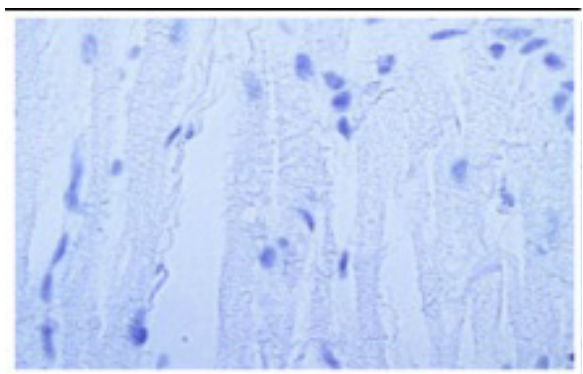

Figure 2. Sectional photomicrograph of myocardium tissue of the rats in control group (TUNEL staining, magnification:100X) 


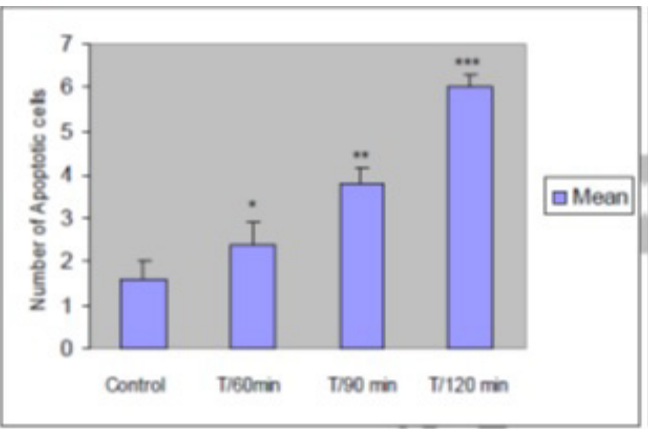

Figure 3. Mean number of apoptotic cells in five view fields of optical microscope in myocardium of control and treatment samples based on TUNEL assay $(n=10)$. The data are illustrated as mean \pm SEM. (comparing with the control group, $* \mathrm{p}>0.05 ; * * \mathrm{p}<0.01 ; * * * \mathrm{p}<0.001)$

tissue. The number of apoptotic cells in the control group was $1.6 \pm 0.4$ and $2.4 \pm 1.14,3.8 \pm 0.836$, and $6 \pm 0.707$ in the treatment groups. Comparison between the treatment and control groups using One-way ANOVA indicated that the difference between $\mathrm{T} / 90 \mathrm{~min}$ and $\mathrm{T} / 120 \mathrm{~min}$ groups and $\mathrm{T} / 60$ and control group was not significant $(\mathrm{p}>0.05)$. However, the difference between $\mathrm{T} / 120 \mathrm{~min}$ and $\mathrm{T} / 60 \mathrm{~min}$ groups $(\mathrm{p}<0.001)$ and between $\mathrm{T} / 120 \mathrm{~min}$ and $\mathrm{T} / 90 \mathrm{~min}$ groups was significant $(\mathrm{p}<0.01)$ (Table 1$)$.

\section{Discussion}

In terms of pathophysiology of cardiomyocytes apoptosis, several pro-apoptotic factors play a role in inducing apoptosis and tissue ischemia-reperfusion is one them that uses several pathway to induce cell apoptosis. Following blood reperfusion, an increase in cell calcium cytosol level happens that results in increase of penetrability potential of mitochondria membrane. Consequently, a large amounts of calcium enter mitochondria and then cytochrome C (Apaf-2) along with Apaf-13, dAtP, and Apaf-3 trigger a cascade of caspases enzymes that results in apoptotic death of the cell. Moreover, high $\mathrm{Ca}++$ content in cytoplasm of cell following tissue reperfusion activates endonuclease enzyme and fragmentation of DNA strains with factor of 180-200 base pairs nucleosomes that trigger apoptotic death of cell [10]. Another pathway in cardiomyocytes apoptosis following reperfusion, which is independent from caspases enzymes, is AIF4 as an apoptosis inducing factor. Increase in the content of cytosol calcium ion penetration to mitochondria triggers this factor and induces apoptosis. The role of time in heart ischemia-reperfusion was examined and the results indicated a significant difference in number of apoptotic cells in the control and treatment groups so that minimum and maximum number of apoptotic cells were observed in the control and $\mathrm{T} / 120 \mathrm{~min}$ groups respectively. This result is consistent with other studies; Albercht Elsasser reported that the highest number of apoptotic cells was observed in $\mathrm{T} / 120 \mathrm{~min}$ reperfusion group $[1,4,5]$. However, their results showed that there was visible apoptotic changes even after $18 \mathrm{hrs}$ of tissue reperfusion. Several factors deal with changes in cellular death including:

1. Cytosol calcium volume that almost reaches its peak value after $60 \mathrm{~min}$ reperfusion, which results in an increase of penetration potential of mitochondria membrane and facilitation of discharge of cytochrome $\mathrm{C}$ and AIF. However, AIF volume is higher than cytochrome C, which is due to the fact that the former is bound to anion phosphor-lipid in intra-membrane space and the latter is not bound in inter-membrane space; this means that AIF can easily cross the membrane $[4,11]$.

2. Expression level of the triggering gens and inducers of apoptosis like BAX, that play a role in formation of mitochondria membrane channels and discharge of cytochrome $\mathrm{C}$, increases in long-term reperfusion and in presence of BAX active protein [12].

3 . Kim et al. reported that activity level of caspase 3 , which is a highly effective factor on apoptosis, increased after $2 \mathrm{hrs}$ reperfusion. Thereby, more changes at $\mathrm{T}=120 \mathrm{~min}$ probably is due presence of adequate volume of caspase enzymes, and caspase 3 in particular [10-12].

At any rate, knowing about the role of time and its effect on tissue reperfusion paves the path for future works on reducing apoptotic changes in tissue reperfusion compounds. Using anti-apoptotic agents along with tissue reperfusion, and heart/liver transplant operation in particular, at proper moment can be highly effective on controlling tissue damages. Given the results and that number of apoptotic cells increases over time, prescribing anti-apoptotic medicines before tissue reperfusion or at early stages of reperfusion is recommended $[2,3,6]$.

\section{Acknowledgements}

The authors wish to thank the Research Department and Mr. Gholamreza Danesh Pazhouhan who helped us as pathology expert.

\section{References}

1. Ambrosio G, Tritto I. Reperfusion injury: experimental evidence and clinical implications. American heart journal. 1999;138(2 Pt 2):S69-75.

2. Deodato B, Altavilla D, Squadrito G, Campo GM, Arlotta M, Minutoli L, et al. Cardioprotection by the phytoestrogen genistein in experimental myocardial ischaemia-reperfusion injury. British journal of pharmacology. 1999;128(8):168390.

3. Eefting F, Rensing B, Wigman J, Pannekoek WJ, Liu WM, Cramer MJ, et al. Role of apoptosis in reperfusion injury. Cardiovascular research. 2004;61(3):414-26.

4. Gao WD LY, Mellgren R, Marban E. . Intrinsic myofilament alterations underlying the decreased contractility of stunned myocardium: a consequence of $\mathrm{Ca} 2+-$-dependent proteolysis? Circ Res 1996; . 455-65. p.

5. Gottlieb RA, Burleson KO, Kloner RA, Babior BM, Engler RL. Reperfusion injury induces apoptosis in rabbit cardiomyocytes. The Journal of clinical investigation. 1994;94(4):1621-8.

6. Kang PM, Izumo S. Apoptosis and heart failure: A critical review of the literature. Circulation research. 
2000;86(11):1107-13.

7. Harper IS BJ, Chacon E, Reece JM, Herman B, Lemasters JJ. Inhibition of $\mathrm{Na}+/ \mathrm{H}+$ exchange preserves viability, restores mechanical function, and prevents the $\mathrm{pH}$ paradox in reperfusion injury to rat neonatal myocytes. Basic Res Cardiol. 1993; 88:430-42.

8. James TN. Apoptosis in cardiac disease. The American journal of medicine. 1999;107(6):606-20.

9. Khoynezhad A, Jalali Z, Tortolani AJ. Apoptosis: pathophysiology and therapeutic implications for the cardiac surgeon. The Annals of thoracic surgery. 2004;78(3):1109-18.

10. Elsasser A, Suzuki K, Lorenz-Meyer S, Bode C, Schaper $\mathrm{J}$. The role of apoptosis in myocardial ischemia: a critical appraisal. Basic research in cardiology. 2001;96(3):219-26.

11. Zhao ZQ, Nakamura M, Wang NP, Wilcox JN, Shearer S, Ronson RS, et al. Reperfusion induces myocardial apoptotic cell death. Cardiovascular research. 2000;45(3):651-60.

12. Kim GT, Chun YS, Park JW, Kim MS. Role of apoptosis-inducing factor in myocardial cell death by ischemia-reperfusion. Biochemical and biophysical research communications. 2003;309(3):619-24.

\section{(c) (i) (8)}

This work is licensed under a Creative Commons AttributionNon Commercial 4.0 International License. 